\title{
Organizational Silence: A Study on Employees of General Directorate of Sports Headquarter $^{1}$
}

\author{
İnci SEÇKİN AĞIRBAŞ ${ }^{\text {iD }}$ a Yasemin ÇAKMAK YILDIZHAN ${ }^{\text {iD }}$ b \\ a Bayburt University, Demirözü Vocational School, Bayburt, Turkey. inciagirbas@bayburt.edu.tr \\ b Erzincan Binali Yıldırım University, School of Physical Education and Sports, Erzincan, Turkey. ycakmak@erzincan.edu.tr
}

\begin{tabular}{|c|c|}
\hline ARTICLE INFO & ABSTRACT \\
\hline $\begin{array}{l}\text { Keywords: } \\
\text { Management } \\
\text { Sport Management }\end{array}$ & $\begin{array}{l}\text { Purpose - Organizational silence is described as employees' remaining silent for various reasons in } \\
\text { the institutions that they work. Organizational silence is one of the situations that affect the labour } \\
\text { productivity in connection with employee productivity. The aim of this study is to specify the } \\
\text { organizational silence perceptions of the employees in the General Directorate of Sports. }\end{array}$ \\
\hline Received 5 March 2020 & $\begin{array}{l}\text { Design/methodology/approach - The survey was carried out among a total number of } 402 \text { people, } \\
162 \text { of which are women and } 240 \text { being men, who work in the General Directorate of Sports. The } \\
\text { demographic features and organizational silence status of the employees were ascertained. The data } \\
\text { obtained were analysed in the SPSS } 22.0 \text { for Windows statistics package software. }\end{array}$ \\
\hline Accepted 4 May 2020 & $\begin{array}{l}\text { Findings - According to the findings of the survey, it was observed that, among sex, marital status } \\
\text { and the tenure of office and the silence levels for the benefit of the organization, there are statistically } \\
\text { significant differences among the silence accepted with title, silence for the benefit of the } \\
\text { organization, and general organizational silence levels. }\end{array}$ \\
\hline $\begin{array}{l}\text { Article Classification: } \\
\text { Research Article }\end{array}$ & $\begin{array}{l}\text { Discussion - In the results of the study, it was concluded that the organizational silence levels of } \\
\text { the employees in the Department of Sports Services vary depending on personal factors. }\end{array}$ \\
\hline
\end{tabular}

\section{INTRODUCTION}

Despite being a commonly observed situation, organizational silence is a new concept in the literature. Organizational silence is described as a negative situation for organizations, yet it is employee's preference to remain silent although they are knowledgeable about the matters and issues of the organization (Çakıc1, 2010). It can be described as a circumstance where the employees do not share their behaviourally, cognitively and emotionally true opinions although they can intervene in an ongoing occasion and are able to change the course of the situation. In other words, despite the fact that it is perceived as a passive behaviour regarding the situation that the person does not express their own ideas and thoughts, organizational silence is evaluated as an active behaviour since the behaviour of remaining silent is realized consciously (Pinder and Harlos, 2001). In short, organizational silence is a situation in which all employees of the organization remain unresponsive to organizational issues (Henriksen and Dayton, 2006).

Silence arises in different forms directly proportional with expectations of employees. These are acquiescent silence, defensive silence and silence for the benefit of organization.

Acquiescent Silence: Acquiescent silence was first proposed by Pinder and Harlos (2001). Employees with acquiescent silence behaviour accept the existing conditions or problems and prefer remaining passive instead of sharing their knowledge, ideas and thoughts with others (Pinder and Harlos, 2001).

Quiescent (defensive) Silence: Fear lies in the basics of this organizational silence type. In this respect, quiescent silence is defined as a person's consciously remaining silent, which results from fearing the bad consequences that they might face when they speak up (Morrison and Milliken, 2000). Employees who show the quiescent silence attitude do not attach importance to the problems of the organization even if they are ${ }^{1}$ This article is extracted from my master thesis entitled "Effects of Presenteeism and Organizational Commitment on Organizational Silence in The Central Organization of Department of Sports Services", (Master Thesis, Erzincan Binali Yıldırım University, Erzincan/Turkey, 2018)

\section{Suggested Citation}

Seçkin Ağırbaş, İ., Çakmak Yıldızhan, Y. (2020). Organizational Silence: A Study on Employees of General Directorate of Sports Headquarter, Journal of Business Research-Turk, 12 (2), 1036-1045. 


\section{İ. Seçkin Ağırbaş - Y. Çakmak Yıldızhan 12/2 (2020) 1036-1045}

aware of them, do not reveal their own personal mistakes, and avoid presenting new opinions even for the benefit of the organization (Çakıc1, 2010).

Prosocial (Protective) Silence: Prosocial silence developed by Van Dyne et.al., (2003) expresses that employees' remaining silent aims at protecting other co-workers and benefits of the organization rather than protecting themselves. The behaviour that the work-related information, opinion and ideas are withheld is based on the will to protect and to benefit for others. Prosocial silence consists of withholding the ideas consciously considering the probable outcomes (Batmuhkh, 2011).

Organizational silence is among the obstacles in good quality and efficient working of organizations and either one or some of the reasons behind organizational silence may lead employees into silence. However, silence is not a sudden decision, but employees prefer it since they consider silence as a behaviour that they have to show or as a circumstance that is a must (Özgen and Sürgevil, 2009). That employees prefer organizational silence negatively affects them as much as it affects the organization. Organizational silence reduces employees' morale, trust and motivation, decreases the loyalty and contentment of employees and causes a decline in the performance of employees by damaging the skill development required for working (Milliken et al., 2003; Brinsfield, 2009). On the other hand, it affects the functions, improvement and decision-making mechanisms of the organization negatively; and it can also prevent the renovation of the organization (Milliken, et al., 2003). Moreover, it obstructs healthy operation of the feedback system and constitutes a problem in detecting the mistakes and deficiencies in the functioning and activities of the organization. Due to the reasons above, it is significant to know the causes of organizational silence and take the required precautions for sports organizations as well as for all organizations.

When the literature is examined, there are not many studies on the concept of organizational silence in sports organizations. This makes this study important. From this point of view, the aim of this study is to specify the organizational silence perceptions of the employees in the General Directorate of Sports. In accordance with this purpose, responses to sub-problems below are investigated:

1. What is the level of organizational silence of the employees in the General Directorate of Sports?

2. Do the organizational silence levels of the employees of the General Directorate of Sports change according to the gender variable?

3. Do the organizational silence levels of the employees of the General Directorate of Sports change according to the marital status?

4. Do the organizational silence levels of the employees of the General Directorate of Sports change according to the tenure of office?

5. Do the organizational silence levels of the employees of the General Directorate of Sports change according to the position title? 


\section{RESEARCH METHODS}

\subsection{Research sample}

The research was based on an availability sample from General Directorate of Sports (around 1000 people). After being informed about the research, the employees voluntarily participated in the survey. The participants were selected randomly. The sample consisted of 402 participants of which $59.7 \%$ were male and $40.3 \%$ female, $51,1 \%$ are between $26-35$ years of age, $70,9 \%$ are married, $65,4 \%$ have received Bachelor's degree, $46,8 \%$ have worked in the institution for $6-10$ years, $56,8 \%$ are expert of sport and $66,2 \%$ have participated in the in-service training (Table 1).

Table 1. Demographic Features of General Directorate of Sports Employees

\begin{tabular}{|c|c|c|c|}
\hline Variable & Group & $\mathbf{f}$ & $\%$ \\
\hline \multirow{2}{*}{ Gender } & Woman & 162 & 40.3 \\
\hline & Man & 240 & 59.7 \\
\hline \multirow{6}{*}{ Age Group } & 25 years and below & 27 & 6.7 \\
\hline & $26-30$ years & 94 & 23.4 \\
\hline & $31-35$ years & 111 & 27.6 \\
\hline & $36-40$ years & 46 & 11.4 \\
\hline & 41-45 years & 76 & 18.9 \\
\hline & 46 years and above & 48 & 11.9 \\
\hline \multirow{3}{*}{ Marital Status } & Single & 94 & 23.4 \\
\hline & Married & 285 & 70.9 \\
\hline & Other (Widow/Divorced) & 23 & 5.7 \\
\hline \multirow{4}{*}{ Educational Status } & Secondary Education & 39 & 9.7 \\
\hline & Associate & 53 & 13.2 \\
\hline & Bachelor's & 263 & 65.4 \\
\hline & Graduate & 47 & 11.7 \\
\hline \multirow{4}{*}{ Tenure of Office } & $1-5$ years & 113 & 28.1 \\
\hline & 6-10 years & 188 & 46.8 \\
\hline & $11-15$ years & 75 & 18.7 \\
\hline & 16 years and above & 26 & 6.5 \\
\hline \multirow{5}{*}{ Position Title } & Administrator & 39 & 9.7 \\
\hline & Expert of sport & 108 & 26.9 \\
\hline & Officer & 120 & 29.9 \\
\hline & Attendant & 46 & 11.4 \\
\hline & Contracted & 89 & 22.1 \\
\hline Total & & 402 & 100 \\
\hline
\end{tabular}

\subsection{Research model}

The research is designed in the survey model. Survey models are approaches that aim to describe events and facts as they were in the past and as they are now (Karasar, 2009). "Organizational Silence" perceptions of the employees in the General Directorate of Sports were measured in line with this view.

\subsection{Research instruments}

In the survey, "Organizational Silence Scale" was utilized which was developed by Van Dyne et. al., (2003) in order to determine the organizational silence perceptions of employees and which was adapted to Turkish by Taşkıran (2010). The scale consists of three sub-dimensions and a total of 15 questions. Questions 1-5 contain inquiries on "Acquiescent Silence", questions 6-10 on "Quiescent Silence" and questions 11-15 on "Prosocial Silence". "Organizational Silence Scale" is a 5-point Likert type scale which is graded with the expressions "strongly disagree", "disagree", "moderately agree", "agree", "strongly agree".

The reliability coefficients of the scale in the survey were determined as .870 for the "Acquiescent Silence" factor, as .813 for the "Quiescent Silence" factor, as .790 for the "Prosocial Silence" factor. The general organizational silence level of the scale was found to be .887 . 


\subsection{Research procedures}

Ethical approval for the research was obtained from the Ethics Committee of the Erzincan Binali Yildirım University $(3 \backslash 9,27.04 .2017)$. Permission for the use of employees was obtained from Ministry of Sport. The research questionnaires were distributed during contact sessions and were completed under the supervision of a lecturer versed in the aims of the study.

\subsection{Statistical analysis}

The data obtained in the survey were analysed in the statistics package software SPSS 22.0 for Windows. As a result of the analyses as to whether the data were distributed normally, the data set was proven not to be distributed normally. The frequency and the percentages of the data regarding the demographic features of the participants that took part in the survey were calculated. Mann-Whitney $U$ test was applied for a comparison of two groups in order to discover if organizational silence levels vary depending on demographical variables; Kruskall-Wallis $\mathrm{H}$ test was used for a comparison of more than two groups and Mann-Whitney U test was applied to determine the odds in binary groups.

\section{RESULTS}

Results are reported in two phases. The first phase of the discussion focuses on the results regarding organizational silence based on selected demographic variables. The second phase includes discussions on the determination of level of organizational silence in the general directorate of sports.

Table 2. Comparison of Organizational Silence Levels of The Employees in The General Directorate of Sports With Respect to Gender Variable

\begin{tabular}{|c|c|c|c|c|c|c|c|c|c|}
\hline Factor & Gender & $\mathbf{N}$ & Min & Max & Median & $\begin{array}{l}\text { Mean } \\
\text { Rank }\end{array}$ & $\begin{array}{c}\text { Sum of } \\
\text { Ranks }\end{array}$ & Z & $\mathbf{P}$ \\
\hline \multirow{2}{*}{ Acquiescent Silence } & Woman & 162 & 5 & 25 & 14.5 & 203.10 & 32903 & \multirow{2}{*}{-.228} & \multirow{2}{*}{.820} \\
\hline & Man & 240 & 5 & 25 & 14 & 200.42 & 48100 & & \\
\hline \multirow{2}{*}{ Quiescent Silence } & Woman & 162 & 5 & 25 & 17 & 196.76 & 31875.5 & \multirow{2}{*}{-.674} & \multirow{2}{*}{.500} \\
\hline & Man & 240 & 5 & 25 & 17 & 204.70 & 49127.5 & & \\
\hline \multirow{2}{*}{ Prosocial Silence } & Woman & 162 & 5 & 25 & 17 & 215.09 & 34844 & \multirow{2}{*}{-1.934} & \multirow{2}{*}{$.053^{*}$} \\
\hline & Man & 240 & 5 & 25 & 16 & 192.33 & 46159 & & \\
\hline \multirow{2}{*}{$\begin{array}{l}\text { General Organizational } \\
\text { Silence }\end{array}$} & Woman & 162 & 23 & 69 & 47 & 205.51 & 33292.5 & \multirow{2}{*}{-.569} & \multirow{2}{*}{.569} \\
\hline & Man & 240 & 15 & 75 & 47 & 198.79 & 47710.5 & & \\
\hline
\end{tabular}

${ }^{*} \mathrm{p}<.05$

When the organizational silence levels of the employees in the General Directorate of Sports with respect to gender variable in Table 2 are analysed, it is observed that the prosocial silence levels of women (MR=215.09) are statistically significantly higher than the prosocial silence levels of men (MR=192.33), and that there are no major statistical differences between two genders of other factors. 


\section{İ. Seçkin Ağırbaş - Y. Çakmak Yıldızhan 12/2 (2020) 1036-1045}

Table 3. Comparison of Organizational Silence Levels of The Employees in The General Directorate of Sports with Respect to Marital Status Variable

\begin{tabular}{|c|c|c|c|c|c|c|c|c|c|}
\hline Factor & Marital Status & $\mathbf{N}$ & Min & Max & Median & $\begin{array}{l}\text { Mean } \\
\text { Rank }\end{array}$ & $\begin{array}{l}\text { Chi- } \\
\text { Square }\end{array}$ & $\mathbf{P}$ & $\begin{array}{c}\text { Groups that } \\
\text { differ }\end{array}$ \\
\hline \multirow{3}{*}{$\begin{array}{l}\text { Acquiescent } \\
\text { Silence }\end{array}$} & Single (1) & 94 & 5 & 22 & 13 & 189.79 & \multirow{3}{*}{1.801} & \multirow{3}{*}{.406} & \multirow{3}{*}{-} \\
\hline & Married (2) & 285 & 5 & 25 & 14 & 206.46 & & & \\
\hline & $\begin{array}{l}\text { Other } \\
\text { (Widow/Divorced) (3) }\end{array}$ & 23 & 5 & 25 & 14 & 187.87 & & & \\
\hline \multirow{3}{*}{$\begin{array}{l}\text { Quiescent } \\
\text { Silence }\end{array}$} & Single (1) & 94 & 5 & 24 & 17 & 189.48 & \multirow{3}{*}{4.839} & \multirow{3}{*}{.089} & \multirow{3}{*}{-} \\
\hline & Married (2) & 285 & 5 & 25 & 17 & 208.68 & & & \\
\hline & $\begin{array}{l}\text { Other } \\
\text { (Widow/Divorced) (3) }\end{array}$ & 23 & 6 & 23 & 15 & 161.65 & & & \\
\hline \multirow{3}{*}{$\begin{array}{l}\text { Prosocial } \\
\text { Silence }\end{array}$} & Single (1) & 94 & 5 & 25 & 17 & 227.95 & \multirow{3}{*}{6.862} & \multirow{3}{*}{$.032^{*}$} & \multirow{3}{*}{$1-3^{*}(.014)$} \\
\hline & Married (2) & 285 & 5 & 25 & 16 & 194.68 & & & \\
\hline & $\begin{array}{l}\text { Other } \\
\text { (Widow/Divorced) (3) }\end{array}$ & 23 & 10 & 25 & 15 & 177.89 & & & \\
\hline \multirow{3}{*}{$\begin{array}{l}\text { General Org. } \\
\text { Silence }\end{array}$} & Single (1) & 94 & 23 & 69 & 47 & 201.69 & \multirow{3}{*}{2.297} & \multirow{3}{*}{.317} & \multirow{3}{*}{-} \\
\hline & Married (2) & 285 & 15 & 75 & 47 & 204.29 & & & \\
\hline & $\begin{array}{l}\text { Other } \\
\text { (Widow/Divorced) (3) }\end{array}$ & 23 & 22 & 71 & 42 & 166.15 & & & \\
\hline
\end{tabular}

${ }^{*} \mathrm{p}<.05$

When the organizational silence levels of General Directorate of Sports employees with respect to marital status variable in Table 4 are compared, it is seen that the prosocial silence factor values of single employees $(M R=227.95)$ are statistically significantly higher than that of widow/divorced ones $(M R=177.89)$, and that there are no statistically significant differences between groups in other factors.

Table 4. Comparison of Organizational Silence Levels of The Employees in The General Directorate of Sports with Respect to Tenure of Office Variable

\begin{tabular}{|c|c|c|c|c|c|c|c|c|c|}
\hline Factor & Tenure of Office & $\mathbf{N}$ & Min & Max & Median & $\begin{array}{l}\text { Mean } \\
\text { Rank }\end{array}$ & $\begin{array}{l}\text { Chi- } \\
\text { Square }\end{array}$ & $\mathbf{P}$ & $\begin{array}{c}\text { Groups that } \\
\text { differ }\end{array}$ \\
\hline \multirow{4}{*}{$\begin{array}{l}\text { Acquiescent } \\
\text { Silence }\end{array}$} & $1-5$ years $(1)$ & 113 & 5 & 24 & 15 & 218.25 & \multirow{4}{*}{6.727} & \multirow{4}{*}{.081} & \\
\hline & $6-10$ years $(2)$ & 188 & 5 & 25 & 14 & 194.97 & & & \\
\hline & $11-15$ years ( 3 ) & 75 & 5 & 25 & 13 & 182.31 & & & \\
\hline & $\begin{array}{l}16 \text { years and } \\
\text { above }(4)\end{array}$ & 26 & 5 & 25 & 16.5 & 231.27 & & & \\
\hline \multirow{4}{*}{ Quiescent Silence } & $1-5$ years $(1)$ & 113 & 5 & 24 & 17 & 202.62 & \multirow{4}{*}{.702} & \multirow{4}{*}{.873} & \multirow{4}{*}{ - } \\
\hline & $6-10$ years $(2)$ & 188 & 5 & 25 & 16 & 197.20 & & & \\
\hline & $11-15$ years $(3)$ & 75 & 6 & 24 & 17 & 206.22 & & & \\
\hline & $\begin{array}{l}16 \text { years and } \\
\text { above }(4)\end{array}$ & 26 & 5 & 25 & 17 & 214.10 & & & \\
\hline \multirow{4}{*}{ Prosocial Silence } & $1-5$ years $(1)$ & 113 & 9 & 25 & 17 & 219.58 & \multirow{4}{*}{9.943} & \multirow{4}{*}{$.019^{*}$} & \multirow{4}{*}{$\begin{array}{l}1-2^{*}(.018) \\
2-4^{*}(.019) \\
3-4^{*}(.044)\end{array}$} \\
\hline & $6-10$ years $(2)$ & 188 & 5 & 25 & 16 & 186.59 & & & \\
\hline & $11-15$ years $(3)$ & 75 & 9 & 22 & 17 & 196.10 & & & \\
\hline & $\begin{array}{l}16 \text { years and } \\
\text { above }(4)\end{array}$ & 26 & 5 & 25 & 19 & 246.31 & & & \\
\hline \multirow{4}{*}{$\begin{array}{l}\text { General } \\
\text { Organizational } \\
\text { Silence }\end{array}$} & $1-5$ years $(1)$ & 113 & 25 & 69 & 48 & 216.18 & \multirow{4}{*}{5.316} & \multirow{4}{*}{.150} & \multirow{4}{*}{ - } \\
\hline & $6-10$ years $(2)$ & 188 & 22 & 75 & 46 & 192.28 & & & \\
\hline & $11-15$ years $(3)$ & 75 & 22 & 69 & 46 & 191.87 & & & \\
\hline & $\begin{array}{l}16 \text { years and } \\
\text { above }(4)\end{array}$ & 26 & 15 & 75 & 52 & 232.13 & & & \\
\hline
\end{tabular}

${ }^{*} \mathrm{p}<.05$ 
When the organizational silence levels of the employees in the General Directorate of Sports with respect to tenure of office variable in Table 6 are compared, it is seen that the factor levels of prosocial silence of employees whose tenure of office is 16 years or more $(M R=246.31)$ is statistically significantly higher than that of employees whose tenure of office is 6-10 years $(\mathrm{MR}=186.59)$ and $11-15$ years $(196.10)$, and so is the factor level of prosocial silence of the ones whose tenure of office is 1-5 years ( $\mathrm{MR}=219.58)$ compared to the factor levels of prosocial silence of employees whose tenure of office is 6-10 years (MR=186.59); and that there are no statistically significant differences between groups in other factors.

Table 5. Comparison of Organizational Silence Levels of The Employees in The General Directorate of Sports with Respect to Position Title Variable

\begin{tabular}{|c|c|c|c|c|c|c|c|c|c|}
\hline Factor & Position Title & $\mathbf{N}$ & Min & Max & Median & $\begin{array}{l}\text { Mean } \\
\text { Rank }\end{array}$ & $\begin{array}{l}\text { Chi- } \\
\text { Square }\end{array}$ & $\mathbf{P}$ & $\begin{array}{l}\text { Groups } \\
\text { that differ }\end{array}$ \\
\hline \multirow{5}{*}{$\begin{array}{l}\text { Acquiescent } \\
\text { Silence }\end{array}$} & Administrator (1) & 39 & 5 & 25 & 16 & 243.33 & \multirow{5}{*}{21.457} & \multirow{5}{*}{$.000^{*}$} & $1-2^{*}(.006)$ \\
\hline & Expert of sport (2) & 108 & 5 & 23 & 13 & 184.60 & & & $1-5^{*}(.001)$ \\
\hline & Officer (3) & 120 & 5 & 25 & 16 & 223.60 & & & $2-3^{*}(.010)$ \\
\hline & Attendant (4) & 46 & 8 & 21 & 17 & 218.37 & & & $3-5^{*}(.001)$ \\
\hline & Contracted (5) & 89 & 5 & 25 & 12 & 165.17 & & & $4-5^{*}(.009)$ \\
\hline \multirow{5}{*}{$\begin{array}{l}\text { Quiescent } \\
\text { Silence }\end{array}$} & Administrator (1) & 39 & 6 & 25 & 17 & 226.36 & \multirow{5}{*}{2.436} & \multirow{5}{*}{.656} & \multirow{5}{*}{-} \\
\hline & Expert of sport (2) & 108 & 5 & 24 & 17 & 194.31 & & & \\
\hline & Officer (3) & 120 & 5 & 25 & 16 & 201.14 & & & \\
\hline & Attendant (4) & 46 & 10 & 21 & 17 & 206.68 & & & \\
\hline & Contracted (5) & 89 & 8 & 25 & 17 & 197.13 & & & \\
\hline \multirow{5}{*}{ Prosocial Silence } & Administrator (1) & 39 & 10 & 25 & 18 & 230.33 & \multirow{5}{*}{15.997} & \multirow{5}{*}{$.003^{*}$} & \multirow{5}{*}{$\begin{array}{l}1-2^{*}(.017) \\
1-5^{*}(.040) \\
2-3^{*}(.001) \\
3-5^{*}(.005)\end{array}$} \\
\hline & Expert of sport (2) & 108 & 5 & 24 & 16 & 178.67 & & & \\
\hline & Officer (3) & 120 & 5 & 25 & 18 & 229.38 & & & \\
\hline & Attendant (4) & 46 & 10 & 22 & 16 & 192.49 & & & \\
\hline & Contracted (5) & 89 & 7 & 25 & 16 & 183.63 & & & \\
\hline \multirow{5}{*}{$\begin{array}{l}\text { General } \\
\text { Organizational } \\
\text { Silence }\end{array}$} & Administrator (1) & 39 & 22 & 75 & 50 & 237.32 & \multirow{5}{*}{17.341} & \multirow{5}{*}{$.002^{*}$} & \multirow{5}{*}{$\begin{array}{l}1-2^{*}(.011) \\
1-5^{*}(.005) \\
2-3^{*}(.004) \\
3-5^{*}(.002)\end{array}$} \\
\hline & Expert of sport (2) & 108 & 22 & 66 & 46 & 182.08 & & & \\
\hline & Officer (3) & 120 & 15 & 71 & 50 & 225.51 & & & \\
\hline & Attendant (4) & 46 & 30 & 61 & 49 & 208.85 & & & \\
\hline & Contracted (5) & 89 & 23 & 75 & 45 & 173.19 & & & \\
\hline
\end{tabular}

${ }^{*} \mathrm{p}<.05$

When the organizational silence levels of the employees in the General Directorate of Sports with respect to position title variable in Table 7 are compared, it is observed that there are no statistically significant differences between groups in the factor levels of quiescent silence whereas acquiescent silence level factor is statistically significantly higher for administrators ( $M R=243.33$ ) and for officers ( $M R=223.60)$ compared to expert of sport $(M R=184.64)$ and contracted $(M R=165.17)$ staff and for attendants ( $M R=218.37)$ compared to contracted $(\mathrm{MR}=165.17)$ staff. It is also clear that prosocial silence and general organizational silence level factors are statistically significantly higher for administrators and for officers as opposed to expert of sport and contracted staff.

\section{DISCUSSION}

When the organizational silence levels of the employees in the General Directorate of Sports with respect to gender are compared, it is observed that there are no major differences between female and male employees in terms of general organizational silence, quiescent silence and acquiescent silence dimensions; however, that women have statistically significantly higher levels than men in terms of prosocial (defensive) silence subdimension ( $\mathrm{p}<.05$ ) is revealed (Table 2). Tulunay et al., (2019) meta-analysis study that investigates the effects of gender and marital status on organizational silence levels of educators shows that defensive (prosocial) silence female educators display a more prosocial silence behaviour than male educators. Baştuğ et. al., (2016) demonstrate in their study on the employees in the General Directorate of Sports that prosocial silence behaviour is observed more with female employees. Moreover, Morrison and Milliken (2000) state that gender 


\section{İ. Seçkin Ağırbaş - Y. Çakmak Yıldızhan 12/2 (2020) 1036-1045}

variable is a factor that affects silence behaviour in their study, as well as Pinder and Harlos (2001) who in their research specify that men prefer expressing their thoughts whereas women endeavour for a consensus and that women have less effects in groups where women and men are together. In their research called, Near and Miceli (1996) reveal that men are more liable to have organizational voice. In another study on gender by Lepine and Van Dyne (1998) it is demonstrated that men behave more comfortably than women when expressing their ideas. In the light of these findings, women are in a more acquiescent attitude against events and situations, and being a woman creates an important hesitation on remaining silent instead of speaking up their thoughts.

On the other hand, a significant relationship between employees' general organizational silence perception and gender variable has not been observed in the research. In the related literature, there are also studies which state that gender does not have an impact on teachers' organizational silence perceptions. In a study held by Bağ and Ekenci (2018) on instructors, an important connection with gender and remaining silent behaviour was not detected. Özdemir and Sarığlu Uğur (2013), Sarıkaya (2013), Nartgün and Demirer (2012), Yanık (2012), Balkan-Akan and Oran (2017), and Öztürk Çiftçi et. al., (2015) reached similar conclusions in their research. As is clear, there is no consistency among the results of studies that examine whether organizational silence behaviour differs depending on gender. The situation can be explained with the fact that the social roles of women and men have become similar within the time course from past to present, and that it arises as the organizational culture differs from one institution to another since each organization owns an idiosyncratic culture no matter their size, age and scope are and the behaviour of individuals in the organization is formed by this culture (Hall, 2005; Altın Gülova and Demirsoy, 2012).

When the organizational silence levels of the employees in the General Directorate of Sports with respect to marital status are compared, it is seen that single employees have statistically significantly higher prosocial silence values than widowed/divorced ones $(\mathrm{p}<.05)$, and there are no significant differences between groups in other factors (Table 3). In the study of Halbaw (2018) on teachers' organizational silence perceptions, the organizational silence levels of single employees are found to be significantly higher than that of married ones. Besides, another finding of the research demonstrates that there are no significant connections between acquiescent silence, quiescent silence and general silence perceptions and marital status. There are other studies in the literature that support this finding (Kolay, 2012; Sarıkaya, 2013; Oruç, 2015; Salha et al., 2016; Gürdoğan and Atak, 2016; Dinçer, 2017; Olğun, 2017; Balkan-Akan and Oran, 2017). Although these studies conclude that marital status does not affect organizational silence, when average values are considered, in some of them, it can be seen that the organizational silence levels of married employees are higher than single ones. In the meta-analysis study that investigates the effects of gender and marital status on organizational silence of educators by Tulunay Ateş and Önder (2019), it is revealed that average impact size of marital status is weak on organizational silence, and organizational silence of married employees are higher than single ones.

When the organizational silence levels in the survey of employees with respect to tenure of office are compared, it is found that prosocial silence factor values are statistically significantly higher for employees with 16 years or more tenure of office compared to the ones with 11-15 years and 6-10 years, and also the values are higher for 1-5 years compared to 6-10 years ( $p<.05)$, and that there are no differences between groups (Table 4) with other factors. This result displays that novice employees and employees working in the institution for a long time constitute more prosocial silence. Nevertheless, that there is no difference between other silence factors and general silence levels also gives rise to a conclusion that tenure of office does not have much effect on silence. When the literature is researched, revealing that tenure of office and organizational silence values are not different (Erenler, 2010; Özdemir and Sarığlu Uğur, 2013; Oruç, 2015; Öztürk and Cevher, 2016; Olğun, 2017). In the studies of Kolay (2012), Nartgün and Demirer (2012), they find that teachers' organizational silence levels do not vary significantly depending on the amount of time they work in the same school.

When the organizational silence levels of the employees in the General Directorate of Sports with respect to position title are compared, while any kind of a difference is not observed between groups in the quiescent silence factor, it is clear that the acquiescent, prosocial and general organizational silence factors for especially administrators and officers as opposed to others are statistically significantly higher (Table 5). Özdemir and Sarığlu Uğur (2013) research on organizational silence specifies that employees' silence values are higher than administrators. Şehitoğlu (2010) research on employees denotes that the ones with the expert status have 
a higher level of silence compared to other employees. Counter to these results, Sarıkaya (2013) and Oruç (2015) state that there are no significant differences between organizational silence levels with respect to the positions of employees. It is seen in the literature that there are different results in the silence levels of employees working in different institutions and organizations with respect to position titles. This situation is considered to arise from institutional differences. When the research is evaluated generally, it demonstrates that the organizational silence levels of the employees in the General Directorate of Sports differ depending on personal factors.

\section{Conclusion and Suggestions}

As a result of our survey, it is clear about the General Directorate of Sports employees that; there are significant differences between prosocial silence levels according to gender, between prosocial silence levels according to marital status and tenure of office, and between acquiescent, prosocial and general organizational silence levels according to position titles.

When the research is evaluated generally, it demonstrates that the organizational silence levels of General Directorate of Sports employees differ depending on personal factors. However, while evaluating the research findings, it is considered that there are some limitations of the study. It is that the research data are derived from quantitative research. This is not situation literally means the causal effects of silence on the results achieved. These results may be inadequate in the explanation. Because silence depends on time, organization and culture is a complex phenomenon that can change.

It is suggested that in order to improve the feelings and thoughts of General Directorate of Sports employees and ergo improve the quality of sports services, it is suggested that employees' situations related to organizations should be studied in different dimensions and be compared to the results of this study. Also by conducting qualitative studies (with long-term observations and interviews) factors affecting organizational silence can be reached.

\section{REFERENCES}

Altın Gülova, A. ve Demirsoy, Ö. (2012). Örgüt kültürü ve örgütsel bağlllık arasındaki ilişki: hizmet sektörü çalışanları üzerinde ampirik bir araştırma. İ̧̧letme ve Ekonomi Araştırmaları Dergisi, 3 (3), 49-76.

Ateş, S. (2013). Resmi ve özel ilköğretim okullarındaki öğretmenlerin örgütsel sessizliğe ilişkin görüşleri (Kırıkkale ili örneği). Yüksek Lisans Tezi, Hacettepe Üniversitesi Sosyal Bilimler Enstitüsü, Ankara.

Bağ, D. ve Ekinci, C.E. (2018). Öğretim elemanlarında örgütsel sessizlik davranışı, nedenleri ve sonuçları. International Journal of Human Sciences, 15 (1), 567-580.

Balkan-Akan, B. ve Oran, Ç. (2017). Akademisyenlerin örgütsel sessizlik algıları: Konuya ilişkin bir uygulama. Kırklareli Üniversitesi İktisadi ve İdari Bilimler Fakültesi Dergisi, 6 (5), 72-90.

Batmuhkh, M. (2011). Liderlik tarzları ile örgütsel bağlllık ve örgütsel sessizlik arasındaki ilişki ve bir araştırma. Doktora Tezi, Marmara Üniversitesi Sosyal Bilimler Enstitüsü, İstanbul.

Baştuğ, G., Pala A., Yılmaz, T., Duyan, M. ve Günel, İ. (2016). Organizational silence in sports employees. Journal of Education and Learning, 5 (4), 126-132.

Brinsfield, C.T. (2009). Employee silence: Investigation of dimensionality, development of measures, and examination of related factors. Master's Thesis, Ohio State University, USA.

Çakıcı, A. (2010). Örgütlerde işgören sessizlĭgi, neden sessiz kalmayı tercih ediyoruz? Ankara. Detay Yayıncılık.

Dinçer, H. (2017). İş yerinde yıldırma ve örgütsel sessizlik arasındaki ilişki: enerji sektörü üzerine bir araştırma. Yüksek Lisans Tezi, Beykent Üniversitesi Sosyal Bilimler Enstitüsü, İstanbul.

Erenler, E. (2010). Çalışanlarda sessizlik davranışının bazı kişisel ve örgütsel özelliklerle ilişkisi: turizm sektöründe bir alan araştırması. Doktora Tezi, Hacettepe Üniversitesi Sosyal Bilimler Enstitüsü, Ankara. 


\section{İ. Seçkin Ağırbaş - Y. Çakmak Yıldızhan 12/2 (2020) 1036-1045}

Gürdoğan, A. ve Atak, O. (2016). Çalışanların demografik özellikleri ile örgütsel sessizlikleri arasındaki ilişki: Beş yıldızlı otel örneği. Uluslararası Sosyal Araştırmalar Dergisi, 9 (44), 1106-1116.

Halbaw, A. (2018). Erbil temel okullarında görev yapan öğretmenlerin örgütsel adalet algilarıyla örgütsel sessizlik arasındaki ilişki. Yüksek Lisans Tezi. İstanbul Kültür Üniversitesi Sosyal Bilimler Enstitüsü, İstanbul.

Hall, M. (2005). Shaping organizational culture: A practitioner's perspective. Peak Development Consulting LLC: (March 9, 2019). http://peakdevelopment.com/wpcontent/uploads/2013/09/PDC_shaping_cult.

Henriksen, K. ve Dayton, E. (2006). Organizational silence and hidden threats to patient safety. Health Services Research, 41 (4p2), 1539-1554. doi: 10.1111/j.1475-6773.2006.00564.x

Karasar, N. (2009). Bilimsel araştırma yöntemi. Ankara, Nobel Yayıncılık.

Kolay, A. (2012). Endüstri meslek liselerinde görev yapan öğretmenlerin örgütsel sessizlik ve örgütsel bağlılıkları arasındaki ilişki. Yüksek Lisans Tezi, Yeditepe Üniversitesi Sosyal Bilimler Enstitüsü, İstanbul.

Lepine, J.A.ve Van Dyne, L. (1998). Predicting voice behaviour in workgroups. Journal of Applied Psychology, (83), 853-868. doi: 10.1037/0021-9010.83.6.853

Milliken, F.J., Morrison, E.W. ve Hewlin, P.E. (2003). An exploratory study of employee silence: Issues that employees don't communicate upward and why. Journal of Management Studies, 40 (6), 14531476. doi:10.1111/1467-6486.00387

Morrison, E.W. ve Milliken, F.J. (2000). Organizational silence: a barrier to change and development in a pluralistic world. The Academy of Management Review, 25 (4), 706-725. doi: 10.2307/259200

Nartgün, Ş.S. and Demirer, S. (2012). Öğretmenlerin örgütsel sessizlik ile iş yaşamında yalnızlık düzeylerine ilişkin görüşleri. Bayburt Ĕ̆itim Fakültesi Dergisi,7 (2), 139-156.

Near, J.P. ve Miceli, M.P. (1996). Whistle - blowing: myth and reality. Journal of Management, 22 (3), 507-526. doi:10.1177/014920639602200306

Olğun, S. (2017). Motivasyon, örgütsel sessizlik ve işten ayrılma niyeti üzerine bir araştırma. Yüksek Lisans Tezi, Marmara Üniversitesi Sosyal Bilimler Enstitüsü, İstanbul.

Oruç, Ş. (2015). Presenteizm ile örgütsel sessizlik arasındaki ilişki üzerine bir araştırma. Yüksek Lisans Tezi, Aksaray Üniversitesi Sosyal Bilimleri Enstitüsü, Aksaray.

Özdemir, L. ve Sarığlu Uğur, S. (2013). Çalışanların örgütsel ses ve sessizlik algılamalarının demografik nitelikler açısından değerlendirilmesi: kamu ve özel sektörde bir araştırma. Atatürk Üniversitesi İktisadi ve İdari Bilimler Dergisi, 27 (1), 257-281.

Özgen, I. ve Sürgevil, O. (2009). Örgütsel sessizlik olgusu ve turizm işletmeleri açısından değerlendirilmesi, Sabuncuoğlu, Z. (Ed.), Turizm İşletmelerinde Örgütsel Davranış, Bursa, MKM Yayıncılık, 303-328.

Öztürk Çiftci, D., Meriç, E. ve Meriç, A. (2015). Örgütsel sessizlik, tükenmişlik ve işten ayrılma niyeti ilişkisi: ordu ili özel eğitim ve rehabilitasyon merkezlerinde bir uygulama. The Journal of International Social Research, 8 (41), 996-1007.

Öztürk, U.C. ve Cevher, E. (2016). Sessizlikteki mobbing: mobbing ve örgütsel sessizlik arasındaki ilişki. KMÜ Sosyal ve Ekonomik Araştırmalar Dergisi, 18 (30), 71 -80.

Pinder, C.C. ve Harlos, K.P. (2001). Employee silence: quiescence and acquiescence as responses to perceived injustice. In Research in Personnel and Human Resources Management, 20, 331-369.

Salha, H., Cinnioğlu, H., Yazıt, H. ve Yenişehirlioğlu, E. (2016). İşgörenlerin örgütsel sessizlik düzeylerinin örgütsel bağlllıklarına etkisi: Tekirdağ'daki yiyecek içecek işletmeleri üzerine bir araştırma. Balkan ve Yakın Doğu Sosyal Bilimler Dergisi, 2 (3), 5-15.

Sarıkaya, M. (2013). Karar verme süreçleri ve örgütsel sessizlik. Yüksek Lisans Tezi, Pamukkale Üniversitesi Sosyal Bilimler Enstitüsü, Denizli. 


\section{İ. Seçkin Ağırbaş - Y. Çakmak Yıldızhan 12/2 (2020) 1036-1045}

Taşkıran, E. (2010). Liderlik tarzının örgütsel sessizlik üzerindeki etkisinde örgütsel adaletin rolü ve bir araştırma. Doktora Tezi, Marmara Üniversitesi SosyalBilimler Enstitüsü, İstanbul.

Tulunay Ateş, Ö.ve Önder, E. (2019). Eğitimcilerin örgütsel sessizliklerinde cinsiyetin ve medeni durumun etkisi: bir meta analiz çalışması. Hacettepe Üniversitesi Eğitim Fakültesi Dergisi, 34 (3), 786-803. doi: 10.16986/HUJE.2018041735

Van Dyne, V.L., Ang, S. ve Botero, C.I. (2003). Conceptualizing employee silence and employee voice as multidimensional constructs. Journal of Management Studies, 40 (6), 1359-1391. doi: 10.1111/14676486.00384

Yanık, C. (2012). Örgütsel sessizlik ile güven arasındaki ilişki ve eğitim örgütlerinde bir araştırma. Yüksek Lisans Tezi, Yeditepe Üniversitesi Sosyal Bilimler Enstitüsü, İstanbul. 